Общая педагогика, история педагогики и образования General pedagogy, history of pedagogy and education

Original article

DOI: $10.17748 / 2075-9908-2021-13-1-123-133$

UDC $378.184 / 37.013 .77$

\title{
SELF-DETERMINATION IMPACT ON MOTIVATION IN THE CONDITIONS OF PROFESSIONAL EDUCATION
}

\author{
Alla G. MIKHAILOVA \\ Sevastopol State University, \\ P.S. Nakhimov Black Sea Higher Naval School, \\ Sevastopol Russia \\ ORCID ID: http://orcid.org/0000-0002-9419-543X \\ steba1971@mail.ru
}

\begin{abstract}
Introduction: Self-determination theory plays a crucial role in selfawareness forming. It suggests that people are motivated to grow and change as well as to be able to become self-determined by three universal psychological needs: for fulfillment of competence, connection, and autonomy. The article examines the main criteria and indicators of self-determination. Socio-pedagogical conditions are proposed which provide the effectiveness of the process of forming social selfdetermination among students.

Materials and methods: the methodological basis is the ideas of personal and professional development as the basis the foundation of achieving a professional "acme" in the works of such scientists as A.S. Anisimov, A.A. Bodalev, A.A. Derkach, V.G. Zazykin, A.K. Markova, N.V. Kuzmina and others. Scientists focused on interdisciplinary connections and integration approaches in the study of the problems of personality self-determination.
\end{abstract}

Results: recommendations are given for the design of activating methods of selfdetermination. The research hypothesis is based on the assumption that the formation of self-determination in the educational process of the university will be effective if proposed conditions are realized: providing the interconnection of formation processes and person's self-development; inclusion of students in a variety of activities in order to acquire social experience and a system of social roles for further selfdevelopment; trainings for motivational growth and classes aimed at developing skills of self-organization and self-regulation in stressful situations.

Discussion and Conclusions: according to these conclusions, a set of recommendations were developed: external and internal factors of social self-determination should be considered in the system, with its inherent connection with the environment, since changes in the social environment entail changes in the system of factors; in order to study personal properties, develop mutual understanding and determine ways of development and correction, one should use high-quality psychodiagnostic techniques, trainings for motivational growth, aimed at developing skills of self- 
organization and self-regulation in stressful situations; it is necessary to ensure the activity of students in a variety of activities.

Keywords: self-determination, motivation, professional education, university students, communicative interaction.

For citation: Mikhailova A.G. Self-determination impact on motivation in the conditions of professional education. Historical and Social-Educational Idea. 2021. Vol. 13. No.1. PP. 123-133. (In Russ.).

DOI: $10.17748 / 2075-9908-2021-13-1-123-133$

\title{
Научная статья
}

\section{ВЛИЯНИЕ САМООПРЕДЕЛЕНИЯ НА МОТИВАЦИЮ В УСЛОВИЯХ ПРОФЕССИОНАЛЬНОГО ОБРАЗОВАНИЯ}

\author{
МИХАЙЛОВА Алла Григорьевна \\ Севастопольский государственный университет; Черноморское высшее военно- \\ морское училище им. П.С. Нахимова \\ г. Севастополь, Россия \\ ORCID ID: http://orcid.org/0000-0002-9419-543X \\ e-mail: Steba1971@mail.ru
}

Аннотация. Введение: Теория самоопределения играет решающую роль в формировании самосознания. Это говорит о том, что люди мотивированы меняться, а также стремиться к самоопределению благодаря трем универсальным психологическим потребностям: достижению компетентности, связи и автономии. Предложены социально-педагогические условия, обеспечивающие эффективность процесса формирования социального самоопределения студентов.

Материалы и методы: методологической основой являются идеи личностного и профессионального развития как основы достижения профессионального «апогея» в трудах таких ученых, как А.С. Анисимов, А.А. Бодалев, А.А. Деркач, В. Зазыкин, А. Маркова, Н.В. Кузьмина и другие. Ученые подчеркнули междисциплинарные связи и интеграционных подходах при исследовании проблем самоопределения личности.

Результаты исследования: даны рекомендации по структуре активирующих методов самоопределения. Гипотеза исследования основана на предположении, что формирование самоопределения в образовательном процессе вуза будет эффективным при реализации условий: обеспечение взаимосвязи процессов формирования и саморазвития человека; включение студентов в различные виды деятельности с целью приобретения социального опыта и системы социальных ролей для дальнейшего саморазвития; тренинги для мотивационного роста и занятия, направленные на развитие навыков самоорганизации и саморегуляции в стрессовых ситуациях.

Обсуждение и заключение: в соответствии с этими выводами был разработан комплекс рекомендаций: внешние и внутренние факторы социального самоопределения должны учитываться в системе, с присущей ей связью с окружающей средой, поскольку изменения социальной среды влекут за собой изменения в системе факторов; для изучения личностных свойств, развития взаимопонимания и 
определения путей развития и коррекции следует использовать качественные психодиагностические методики, тренинги для мотивационного роста, направленные на развитие навыков самоорганизации и саморегуляции в стрессовых ситуациях; необходимо обеспечить активность студентов в самых разных видах деятельности.

Для цитирования: Михайлова А.Г. Влияние самоопределения на мотивацию в условиях профессионального образования.// Историческая и социальнообразовательная мысль. 2021. Том. 13. № 1. с. 123-133

DOI: 10.17748/2075-9908-2021-13-1-123-133

Acknowledgement: I express my gratitude to the anonymous reviewers. Благодарность: выражаю благодарность анонимным рецензентам.

Introduction: Self-determination can play an important role in people's motivation during professional education, which can help them feel more committed, interested, and satisfied with done things.

In psychology, self-determination is an important concept that refers to each person's ability to make choices and manage one's own life. This ability plays an important role in psychological health and well-being [14]. Self-determination allows people to feel that they have control over their choices and lives. It also has an impact on motivation - people feel more motivated to take action when they feel that what they do will have an effect on the outcome" $[15, \mathrm{www}]$.

To provide the growth of stronger self-determination one should improve:selfawareness; self-regulation; goal-setting abilities; decision-making skills.

In the course of communicative interaction, a person realizes one's place in society [13], the result of which is self-determination as a formed self-awareness [12]. At the same time, despite significant innovations in the field of content and technology of education, universities do not provide the level of personal training that would correspond to the renewal of target, content and procedural characteristics of production, since the social functions of higher education have been lost.

The methodological foundations of the problem of self-determination were studied by S.L. Rubinstein, who characterized self-determination as one, which expresses the essence of the principle of determinism: "its meaning is to emphasize the role of the inner moment of self-determination, loyalty to oneself, non-sided subordination to the external" [17, p. 382].

It would be useful to refer to self-determination theory. It suggests that people are motivated to grow and change as well as to be able to become self-determined by three universal psychological needs: for fulfillment of competence, connection, and autonomy.

- Competence: Students need to learn different skills. "They are more likely to take actions that will help them achieve their goals" [15, www].

- Connection or Relatedness: Student needs "to experience a sense of belonging and attachment to other people" [15, www].

- Autonomy: Student need to feel in control of her/his own goals. This sense plays a major part in helping students feel self-determined [15].

"Self-determination of a person is a complex scientific problem with philosophical, sociological, psychological and pedagogical aspects» [21, p. 29]. 
There are three types of motivation involved in the test-taking process: motivation in the actional phase; one in the preactional phase and one in the postactional phase. The last phase is considered to be the most important because it cause the student to improve one's skills.

The three above mentioned major theoretical frameworks in motivation (the Achievement Goal Theory, Self-Determination Theory and Expectancy-Value Theories) are the foundation of motivation. "Different instruments aiming at measuring the degree of motivation in tests have also been developed and tested based on these theoretical frameworks, however, these tools are mostly context specific and therefore so far none of them can said to be better than the others or being seen as 'the' instrument" [20, www].

Material and methods: the methodological basis is the ideas of personal and professional development as the basis the foundation of achieving a professional "acme" in the works of such scientists as A.S. Anisimov, A.A. Bodalev, A.A. Derkach, V.G. Zazykin, A.K. Markova, N.V. Kuzmina and others. Scientists focused on interdisciplinary connections and integration approaches in the study of the problems of personality self-determination.

Analysis of domestic and foreign sources and pedagogical practice indicate that the following contradictions take place in modern education:

- between the need of society for competent specialists who have social responsibility and are ready for productive interaction, and the low level of this readiness formation among university graduates;

- between the need for changes in higher education aimed at the development of selfdetermination, and the lack of conditions for the effectiveness of this process.

The need to resolve these contradictions made it possible to formulate the problem: what are the ways of self-determination forming and how does it impact on students' motivation in the conditions of professional education.

The purpose of the study is theoretical substantiation and experimental and verification of a set of conditions under which the formation of self-determination will be effective.

The research hypothesis is based on the assumption that the formation of selfdetermination in the educational process of the university will be effective if the following conditions are realized:

- a system of criteria and indicators for assessing the levels of self-determination among students in the educational process of the university has been determined;

- the method effectiveness of forming self-determination in the process of the experiment was checked.

In accordance with the intended goal, object, subject and hypothesis, the following research tasks were set:

1) to clarify the content of the concept of "social self-determination" based on the analysis of foreign and domestic experience;

2) to determine the system of criteria and indicators for assessing the levels of formation of person's self-determination;

3 ) to develop a methodology for the formation of self-determination among students;

4) to conduct experimental work on the implementation and verification of the conditions under which the formation of self-determination will be effective.

The research methodology was based on: psychological aspects of the problem of personality development (K.A. Abulkhanova-Slavskaya, B.G. Ananiev, L.S. Vygotsky, A.N. Leontiev, S.L. Rubinstein, V.I. Slobodchikov, etc.). 
To solve the problems posed in the study and verify the initial assumptions, a set of complementary research methods was used: theoretical: (analysis of philosophical, sociological, psychological, pedagogical, social literature on the problem under consideration; analysis of documentation on the organization of the educational process at the university; analysis, synthesis, and systematization for theoretical generalization of the main approaches to solving the research problem); experimental: methods of participatory observation, active learning and modeling, analysis of performance results, as well as psychodiagnostic techniques; experimental activity and pedagogical experiment.

Results: many scientists have studied the individual elements of the phenomenon of self-determination. From the standpoint of philosophy and sociology, the concept of "selfdetermination" was defined as a property of consciousness, which can be considered:

- in the context of the social formation of an individual, its entry into social spheres and the development of norms, attitudes, values adopted in society $[1-2 ; 10 ; 17 ; 18]$;

- as a key element of psychological well-being; people like to feel in control of their lives;

- as a conscious independent choice of a person's life path and positions, the choice of values, moral norms, profession, religion, living conditions [2];

- as the presence of an active life, personal and professional position [2-5].

The concept of "social self-determination" was defined as:

- the phenomenon of group interaction, which manifests itself in specially designed situations of group pressure [12];

- a person's choice of criteria, norms of self-assessment, values: what is needed for society [11];

- the person's awareness of his/her position, which is formed within the coordinates of the system of relations and how it develops (to the collective subject, to his place in the team), the social activity of the individual and social self-determination depend [1;17];

- a structural component of a person's life self-determination, associated with the development of a person at all stages of a person's life; search for the realization of personal inclinations and abilities within the framework of activities based on individual life and social attitudes [21];

- a person's revision of the criteria used by him at various stages of one's development, since values and mentality in society itself change $[3,4,18]$.

Although social self-determination is a goal for people, it is impossible not to be guided by external sources. Motivation not only contributes to the effectiveness of interaction, but also undermines it, depending on the existing social and environmental factors [5].

Both intrinsic and extrinsic motivations are very important determinants of human behavior that motivate us to meet three basic needs:

1. Autonomy: people need to feel that they can control their behavior.

2. Competence: achievements, knowledge and skills that need to be developed.

3. Connection: each of us in one way or another needs other people

Taking into an account the theory of needs by E. Desi and R. Ryan, we take into account that interpersonal events and feedback, which are directed to a sense of competence when performing an activity, enhance the internal motivation of interaction [3].

Based on the above, we consider social self-determination as a mechanism of social determination, which is influenced by the individual's own activity. The future professional activity of the subject of interaction is inevitably associated with the emergence of social situ- 
ations of professional development, the progressive resolution of which, ultimately, leads to the achievement of productive work [4].

In connection with the diagnosis of the considered social self-determination, there is a need to study its dynamics and characterize the levels of formation. For this purpose, we have identified the relevant criteria and indicators. In the scientific literature, a criterion is understood as a feature on the basis of which an assessment, determination or classification is carried out, a method of verification.

When identifying the criteria, we relied on structural analysis. In our opinion, a criterion of the same name can correspond to each structural component of social selfdetermination.

In the structure of social self-determination of a person, we have identified the needtarget, cognitive, emotional-volitional, activity, reflexive-value criteria.

The need-target criterion is characterized by the formation of the individual's need for communicative interaction, the desire to gain readiness for interaction. The cognitive criterion is characterized by the formation of knowledge. Cognitive interests of students in a certain area of knowledge and practical activity are combined with the cognitive attitude of the individual to activity, understanding its value and significance. The reflexive-value criterion is characterized by the formation of the personal value-semantic foundations of selfdetermination (personal values, experiences, social responsibility), which ensure the process of personification of the personality. The activity criterion is represented by the attitude of the individual and the world around, his/her readiness and ability to creatively transform reality.

In each criterion, we have identified indicators that can be used to describe the quality of social self-determination of a university student.

The need-target criterion as the formation of the individual's need for communicative interaction, the desire to gain readiness for interaction includes indicators: the presence of needs for communicative interaction, readiness for communication, and focus on the formation of communicative skills in students.

The cognitive criterion as the formation of professional knowledge includes indicators: the presence of knowledge in a particular area, intersubject erudition. The reflexive-value criterion as the formation of personal value-semantic foundations includes, as indicators, the presence of communicative and organizational-evaluative skills, social responsibility. The activity criterion as the formation of the readiness and ability to creatively transform oneself and reality includes the readiness for self-development, the ability for self-improvement. On the basis of the selected criteria and indicators, it is possible to investigate the qualitative and quantitative characteristics of such a complex personal formation as social self-determination.

Discussion and Conclusions: the pedagogical experiment made it possible to develop a scale of levels of social self-determination in accordance with the criteria. This scale, which includes three levels: high, medium, low, was determined by us based on the results of the respondents' answers. The main experimental work was carried out on the basis of the University.

Diagnostics of the level of social self-determination of a person should be comprehensive and include pedagogical testing. Since there are two main elements of self-determination - internal (the urge to certain behavior based on external sources, which leads to external rewards) and external (regulated by obedience, compliance, as well as external rewards and punishments, which determine human behavior), we single out the external and internal criteria of social self-determination, which we diagnosed using the locus of control technique. 
External and internal factors of social self-determination must be considered in the system, with its inherent connection with the environment. Changes in the social environment entail changes in the system of factors.

The Sevastopol State University became the experimental base of the research. 78 students took part in the research work (45 people - in the control group, 33 - in the experimental group). Organization and stages of research: ascertaining (2018) - implementation of empirical research; formative (2019) - implementation of the developed socio-pedagogical conditions and control stage (2020) - analysis of the results obtained, comparison of data with the ascertaining stage.

To determine the level of formation of the need-target component, we applied "Need for communication" methodology by Yu. M. Orlov, which measures the immediate needs associated with activity in the field of communication and the method "Assessment of the need for approval" or "Scale of social desirability" D. Crown and D. Marlowe to measure the severity of social desirability [16, p. 138]. One can also use the "Diagnostics of the need to seek sensations" by M. Tzuckerman, which measures an inclination to risky behavior, "Questionnaire by Yu. Orlov" to measure the need in achieving.

To measure the level of formation of the cognitive component, we used the "Study of the prevailing type of memorization" technique, the purpose of which is to reveal the prevailing amount of memory for different types of presentation of verbal material. "The study consists of four experiments. In the first experiment, words for memorization are presented by ear. In the second - visually, and each word should be clearly written on a separate card. In the third experiment, the motor-auditory form of presentation is used, and in the fourth, the combined one, which combines auditory, visual and motor perception of the material" $[16, p$. 45].

To determine the level of formation of the emotional-volitional component "The ability of a person to self-determination and self-regulation, orderliness, purposefulness and consciousness is possible due to volitional manifestations of the personality. Will is a mental function that literally permeates all aspects of a person's life, makes him free from external influences" [16, p. 70].

The concept of will is associated with the concept of Locus control, which is based on the opinion about the difference between people in terms of where they localize control over significant events. "Locus control (from Latin "locus" is place, location and French "controle"- check) is a quality that characterizes a person's tendency to ascribe responsibility for the results of one's activities (internal locus of control) or to circumstances (external locus control)" [16, p. 70].

Locus of control refers to the extent to which a person feels that he/she has control over the events that influence lives. "When you are dealing with a challenge in your life, do you feel that you have control over the outcome? Or do you believe that you are simply at the hands of outside forces?" [5, www].

Psychologists refer to as an internal locus of control when you believe that you have control over what happens. And if you have no control, then you have what is stated as an external locus of control. "Your locus of control can influence not only how you respond to the events that happen in your life, but also your motivation to take action Locus of Control and Your Life" [5, www].

Internal type. A person believes that occurring events depend, first of all, on his/her personal qualities (competence, purposefulness, level of abilities, etc.) and are natural consequences of his/her own activity. 
External type. A person is convinced that his/her successes and failures depend, first of all, on external circumstances - environmental conditions, the actions of other people, chance, luck or bad luck, etc.

The directionality of the locus of control should be considered as the relative excess of the results of one measurement over another. In the practice of psychodiagnostics, the locus of control characterizes the cognitive style manifested in the field of education, including professional.

The results of diagnostics of the locus of control showed that the most of the students are of the external type. Most of the respondents are convinced that their successes and failures depend primarily on external circumstances - the actions of other people, environmental conditions, etc., which proves the need for the development of social self-determination. Internal locus of control is often used synonymously with "self-determination" and "personal agency". In general, persons with an internal locus of control tend to be better off. "In some situations, having an external locus of control can be a good thing - particularly when a person's level of competence in a particular area is not strong. For example, a person who is terrible at sports might feel depressed or anxious about their performance if they have a strong internal locus of control" [20, www].

In order to study the level of communicative actions in the structure of selfdetermination, we tested the methodology "Assessment of the activity component", based on solving practical tasks. Students of the control and experimental groups were asked to complete a series of sequentially presented tasks, each of which was a logical continuation of the previous one. All tasks are based on solving conflict situations.

The reflexive-value component of social self-determination is a complex system that includes all the skills for self-organization. Therefore, it was diagnosed based on an assessment of the skills of professional self-organization. The research procedure included the questionnaire "Diagnostics of the peculiarities of self-organization - 39 (DOS-39)" by N.G. Miloradova, A.D. Ishkova [8].

The development of social self-determination of university students is an expediently organized personality-oriented educational process. For each stage, pedagogical goals and expected results, organizational forms, methods and means used for the consistent development of social self-determination are determined.

Knowledge of the theoretical foundations of the process of social self-determination is a guarantee of high-quality preparation of graduates for conscious readiness for group interaction. The model of integration of full-time and distance forms in education is considered as promising in the development of social self-determination.

The creation of social and pedagogical conditions for productive learning, upbringing and personality development in the educational process ensured the effectiveness of the process of forming students' social self-determination, namely:

- providing the interconnection of formation processes and person's selfdevelopment [21];

- inclusion of students in a variety of activities in order to acquire social experience and a system of social roles for further self-development;

- trainings for motivational growth and classes aimed at developing skills of selforganization and self-regulation in stressful situations.

In the experimental group, training was conducted with the implementation of the proposed social and pedagogical conditions; in the control group, classes were conducted in the traditional way without taking into account the recommendations of our study. 
At the first stage, the interconnection of formation processes and self-development of a personality was ensured on the basis of trainings for motivational growth. "Social and psychological training of program-targeted orientation" was used, which had the following structure: organizational moment; the main part, including the motivational moment and the broadcast of new content; summing up and homework. For the formation of empathic abilities, training was applied, the purpose of which was to create conditions for improvement and personal growth, to form the ability to analyze one's own emotional world and the ability to empathize with others.

The main objectives of the training were: awareness of their experiences; the formation of observation; development of skills to understand non-verbal signals of another person; formation of the ability to empathize with the interlocutor.

At the second stage, training was conducted to increase self-esteem and develop the ability to make decisions. One of the primary goals of rope training is to build and build trust in people.

At the third stage, work was carried out in small groups with the methods "Brainstorming", TRIZ, Algorithm for solving inventive problems.

Recommendations proposed by Kendra Cherry were used to increase motivation [4]. "It is known that people often feel more motivated when they have control over the situation. One of the main reasons students dislike "group work" is that they lose their individual sense of control and contribution.

To take back control in group interaction students should

- find a way to make each person feel empowered and influential;

- do not prevent others from putting forward their ideas;

- allow group mates to determine what goals they wish to pursue" [ $\underline{4}, \mathrm{www}]$.

Diagnostics of levels after the formative experiment was carried out by means of diagnostic tests. For each of the previously identified criteria, we analyzed the dynamics of changes in the levels of students' social self-determination formation.

The results of the data obtained indicated that the complex of pedagogical conditions aimed at the effective formation of social self-determination significantly increased the high level of the respondents of the experimental group in comparison with the results of the initial diagnosis during the ascertaining experiment.

Thus, a comparative quantitative analysis of the results of experimental work showed the effectiveness of the proposed socio-pedagogical conditions in the process of forming social self-determination. The results obtained prove the necessity and expediency of the developed and experimentally tested methodology.

A comparative qualitative analysis of a stable personality characteristic (Locus of control), reflecting a person's predisposition to explain the causes of events by external or internal factors, made it possible to identify problems and outline prospects for their solution.

According to these conclusions, we have developed a set of recommendations:

1) for the purpose of the effectiveness of the process under study, external and internal factors of social self-determination should be considered in the system, with its inherent connection with the environment, since changes in the social environment entail changes in the system of factors;

2) in order to study personal properties, develop mutual understanding and determine ways of development and correction, one should use high-quality psychodiagnostic techniques, trainings for motivational growth, aimed at developing skills of self-organization and self-regulation in stressful situations; 
3) in order to acquire social experience and a system of social roles for further selfdevelopment, it is necessary to ensure the activity of students in a variety of activities.

Methods of increasing motivation in order to form self-determination within the framework of inclusive education are prospects for further research.

\section{REFERENCES}

1. Abulkhanova-Slavskaya A.K. Strategy of life. M., 1991. 230 p.

2. Ananiev BG Man as a subject of knowledge. 3rd edition. Series: Masters of Psychology SPb.: Peter, 2016; 288 p.

3. Cherry Kendra. Self-Determination Theory and Motivation. October 07, 2019; URL: https://www.verywellmind.com/what-is-self-determination-theory-2795387 [accessed 10 December 2020].

4. Cherry Kendra. 5 Surprising Ways to Get Motivated. Psychological techniques to help you get more motivated. July 23, 2020; URL: https://www.verywellmind.com/surprising-ways-to-get-motivated-2795388 [accessed 10 December 2020].

5. .Courtney E. Ackerman, MSc. Self-Determination Theory of Motivation: Why Intrinsic Motivation Matters. URL: https://positivepsychology.com/self-determination-theory/ [accessed 10 December 2020].

6. Golovakha E.I. Life perspective and professional self-determination. Kiev: Naukova Dumka, 1988.144 p.

7. Golovko O.N., Korepanov A.L., Lei V.A. Pedagogical professionalism as a factor in the development of student's abilities. Modern Science. № 5-1, 2020; Pp. 325-329.

8. . Ishkov A.D. Educational activity of a student: psychological factors of success: Monograph M.: ACB, 2004; 224 p.

9. . Kostsova M.V., Mikhailova A.G., Grishina A.V., Chunikhina L.V. Features of professional motivation among counselors with different pedagogical experience (on the example of ICC “Artek. Modern Science. № 11-1, 2020; Pp. 351-357

10. . Leontiev D.A., Shelobanova E.V. Professional self-determination as the construction of images of a possible future. Questions of psychology, 2001; № 1. p. 57-65.

11. . Markova A.K. Psychology of professionalism. Publisher: International Humanitarian Foundation "Knowledge". URL: https://www. studmed.ru/markova-ak-psihologiyaprofessionalizma_6b2fa1cadce.html [accessed 05 December 2020].

12. . Mikhailova A.G., Kostsova M.V. Stages of the formation of readiness to overcome emotional barriers of communication. Historical and Social-Educational Idea., v12. № 3 . 2020; p. 101-119 DOI: https://doi.org/10.17748/2075-9908-2020-12-3-101-119

13. . Mikhailova A.G., Golovko O.N. Formation of professional and communicative competence in the practice of the university (on the example of IT specialists). International scientific journal, 2020; № 2. p. 34-37.

14. . Mikhaylova A.G., Nikitaeva M.V., Kokodey T.A. Formation of personal qualities by means of acmeological approach in the context of professional becoming. Volume 87, 000282020. International Scientific and Practical Conference "Teacher Professionalism: Psychological and Pedagogical Support of a Successful Career" (ICTP 2020) DOI: https://doi.org/10.1051/shsconf/20208700028 [accessed 10 December 2020].

15. . Motivation and Psychological Well Being Across Life's Domains. Canadian Psychology Copyright 2008 by the Canadian Psychological Association 2008; v 49, No. 1, p. $14-23$

16. . Psychological diagnostics of personality spheres [Electronic resource]: laboratory practice. Ural. state ped. un-t; author-comp. Yu.E. Vodyakha. Electron. Dan. Ekaterin- 
burg, 2018. 1 electron. disk (CD-ROM)

17. . Rubinstein S.L. Principle of creative amateur performance: To the philosophical foundations of modern pedagogy. Questions of psychology. Scientific archive. p. 101-109 URL: http://voppsy.ru/issues/1986/864/864101.htm (date of access: 03.11.2020) [accessed 10 December 2020].

18. . Serikov G.N. Socially significant aspects of personality self-determination Bulletin of SUSU. Education. Pedagogical Sciences. 2014; v6, № 4. p. 27-32.

19. . Self-determination URL: https://www.britannica.com/topic/self-determination [accessed 10 December 2020].

20. . TSANG Hoi Ka. Student Motivation on a Diagnostic and Tracking English Language Test in Hong Kong Carrie. Institute of Education. University of London. 2013; p. 44 URL: https://discoveryucl.ac.uk/id/eprint/10017892/1/Thesis_ _Carrie_Tsang)_Final\%20copy.pdf [accessed 10 December 2020].

21. . Zhurkina A.Ya. Sergushin E.G., Sergushina O.V. Theoretical aspects of the formation of social and professional self-determination of students of educational organizations. Integration of education. 2016; v.20. № 1. p. 29-36.

Information about the author: Alla G. Mikhailova, senior lecturer, Foreign Languages Department, Sevastopol State University; senior lecturer, Foreign Languages Department, P.S. Nakhimov Black Sea Higher Naval School, Sevastopol

ORCID ID: http://orcid.org/0000-0002-9419-543X

steba1971@mail.ru

The author has read and approved the final manuscript

Информация об авторе: Михайлова Алла Григорьевна, ст. преподаватель кафедры «Иностранные языки», Севастопольский государственный университет, ул. Университетская 33, г. Севастополь. Ст. преподаватель кафедры «Иностранные языки», Черноморское высшее военно-морское училище им. П.С. Нахимова, ул. Парковая 10, г. Севастополь

ORCID ID: http://orcid.org/0000-0002-9419-543X

e-mail: Steba1971@mail.ru

Автор прочитал и одобрил окончательный вариант рукописи

Статья поступила в редакцию / The article was submitted: 13.01.2021

Одобрена после рецензирования и доработки / Approved after reviewing and revision: 28.01.2021

Принята к публикации / Accepted for publication: 20.02.2021

Автор заявляет об отсутствии конфликта интересов./ The author declares no conflicts of interests 